\title{
The South African Class Action Mechanism: \\ Comparing the Opt-In Regime to the Opt-Out Regime
}

T Broodryk

\section{P.E.R}

Pioneer in peer-reviewed, open access online law publications

Author

Theo Broodryk

Affiliation

Stellenbosch University

South Africa

Email tbroodryk@sun.ac.za

Date Submission

20 February 2018

Date Revised

13 January 2019

Date Accepted

13 January 2019

Date published

20 May 2019

Editor Prof K Beiter

How to cite this article

Broodryk T "The South African

Class Action Mechanism:

Comparing the Opt-In Regime to the Opt-Out Regime" PER / PELJ 2019(22) - DOI

http://dx.doi.org/10.17159/1727-

3781/2019/v22i0a4506

\section{Copyright}

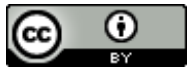

DOI

http://dx.doi.org/10.17159/1727 3781/2019/v22i0a4506

\section{Abstract}

In Mukaddam v Pioneer Food (Pty) Ltd 20132 SA 254 (SCA), Nugent JA stated that, once the class is confined to claimants who choose positively to advance their claims and are required to come forward for that purpose, he can see no reason why they are not capable of doing so in their own names through joinder - they do not need a representative to do so on their behalf. The members who choose to opt in to the class action will thus be identifiable. If that is the case then, according Nugent JA, joinder may be the appropriate procedural device. A problem evidenced by this approach is accordingly that, by suggesting that joinder is the appropriate procedural device where all the claimants are identifiable, rather than a class action, the court essentially attacked the viability of the opt-in regime of class action litigation.

The preferential treatment afforded by our courts to the opt-out class action regime is further reinforced by the finding of Nugent JA that the opt-in class action regime can be utilised only in exceptional circumstances. As exceptional circumstances had not been proved, he found that a class action was not the most appropriate way to pursue the claims. He accordingly suggested that joinder was a viable option to pursue the claims.

The opt-in class action regime requires individual class members to take positive steps to participate in the class action. In other words, class members are required to come forward and opt into the class action, failing which they will not be bound by or benefit from the outcome of the litigation. Support for the opt-in regime is essentially premised on the belief that individuals who are unaware of the litigation should not be bound by its outcome. The opt-out class action regime, on the other hand, automatically binds members of the class to the class action and the outcome of the litigation unless the individual class members take steps to opt out of the class action. Support for the opt-out regime is essentially based on the view that the opting-in requirement could undermine one of the primary purposes of class action litigation, which is to facilitate access to justice.

The Constitutional Court in Mukaddam v Pioneer Foods (Pty) Ltd 20135 SA 89 (CC) held that Nugent JA was wrong to find that an applicant in an opt-in class action is required to show exceptional circumstances. However, the court did not provide reasons for its disagreement. The issue relating to exceptional circumstances in opt-in class actions was dealt with in two sentences. The Constitutional Court also failed to deal with the nature and status of the opt-in class action compared with opt-out class actions in South African law.

The note will accordingly consider when, if at all, it is appropriate to use the opt-in class action regime compared to the opt-out class action regime.

\section{Keywords}

Class action; joinder; notice; opt-in; opt-out; res judicata. 


\section{Introduction}

Nugent JA in Mukaddam v Pioneer Foods (Pty) Ltd ${ }^{1}$ held that, once the class is confined to claimants who choose positively to advance their claims and are required to come forward for that purpose (that is, choosing to "optin"), he can see no reason why they are not capable of doing so in their own names through joinder - they do not need a representative to do so on their behalf. ${ }^{2}$ By suggesting that joinder is the appropriate procedural device where all the claimants are identifiable, Nugent JA clearly questioned the viability of the opt-in regime of class action litigation. He also held that the opt-in class action regime could be utilised only in exceptional circumstances. ${ }^{3}$ As exceptional circumstances were not proved, he found that a class action was not the appropriate way to pursue the claims. ${ }^{4}$

The Constitutional Court (CC) in Mukaddam v Pioneer Foods (Pty) Ltd ${ }^{5}$ held that the Supreme Court of Appeal (SCA) in Mukaddam SCA was wrong to find that an applicant in an opt-in class action is required to show exceptional circumstances. Although the $\mathrm{CC}$ did not provide reasons for its disagreement with the finding of the SCA in this regard, the fact of the matter is that, as our law currently stands, there is no need to prove exceptional circumstances to be able to utilise the opt-in procedure.

It is therefore currently unclear regarding when, if ever, it is appropriate to use the opt-in class action regime rather than the opt-out class action regime. In the absence of legislation regulating class actions, our courts have not provided sufficient guidance on this issue.

The South African Law Commission ${ }^{6}$ (SALC) recommended that courts should have a discretion to make opt-in, opt-out or no notice orders. ${ }^{7}$ However, the approach of the court in Mukaddam SCA regarding the opt-in class action regime, as mentioned above, contradicts this recommendation. It also complicates the issue of notice in class action proceedings. This note

Theo Broodryk. BA LLB LLD (US). Head: Stellenbosch University Law Clinic and Senior Lecturer, Stellenbosch University, South Africa. E-mail: tbroodryk@sun.ac.za.

$1 \quad$ Mukaddam v Pioneer Foods (Pty) Ltd 20132 SA 254 (SCA) (hereafter Mukaddam SCA)

Mukaddam SCA para 12.

If the effect of Nugent JA's comment that joinder is appropriate where all the class members are identifiable is to negate the need for a South African opt-in class action regime, then Nugent JA seemingly contradicts himself by requiring that exceptional circumstances must be proved before the opt-in procedure can be used.

Mukaddam SCA paras 11, 14.

Mukaddam v Pioneer Foods (Pty) Ltd 20135 SA 89 (CC) (hereafter Mukaddam CC). At the time it was known as the South African Law Commission. It became the South African Law Reform Commission in 2002.

SALC Project 88-Report para 5.10.24. 
will accordingly consider the nature and status of the opt-in class action compared with the opt-out class action and, in view of Nugent JA's comments, when, if at all, the opt-in procedure should be utilised rather than the opt-out procedure. ${ }^{8}$

In an opt-out class action, individuals who fall within the class definition are automatically included in the class unless an individual affirmatively requests exclusion from the class. In other words, class members are provided with an opportunity to opt out if they do not wish to be part of the class action. ${ }^{9}$ Consequently, class members who do not opt out are bound by the outcome of the class action. ${ }^{10}$ Class members who choose to opt out are at liberty to pursue individual claims against the defendant.

In an opt-in class action, individual class members who fall within the class definition must affirmatively request inclusion to form part of the class action. Class members who do not opt into the class action are not bound by its outcome and they will accordingly be at liberty to pursue individual claims against the defendant. Naturally, they will also forfeit the opportunity to share in the benefits obtained by the class in the event of a favourable judgment.

Support for the opt-out regime is based essentially on the view that the optin requirement could undermine one of the primary purposes of class action litigation, which is to facilitate access to justice. ${ }^{11}$ It has also been argued that the opt-in regime presupposes that failing to opt in is the result of a properly contemplated decision by the individual class member not to participate in the class action. However, this is not necessarily always the case, especially in South Africa, where the existence of financial and social barriers could result in a failure to opt in. Such a requirement could accordingly defeat the primary purpose of class actions, namely access to justice, especially where small individual claims are involved. ${ }^{12}$

Conversely, support for the opt-in regime is essentially premised on the belief that individuals who are unaware of the litigation should not be bound by its outcome. In other words, in the absence of proper notice of the class proceedings, an individual should not be bound by the judgment of the court in the matter. Proponents of the opt-in regime further argue inter alia that it makes it easier for class members to assess ${ }^{13}$ whether they are being adequately represented in the proceedings, since they are required to act

The CC in Mukaddam CC did not properly engage with these issues.

See, for example, s 9 of the Class Proceedings Act, 1992, SO 1992, c 6.

See, for example, s 27(3) of the Class Proceedings Act, 1992, SO 1992, c 6.

SALC Project 88 - Report para 5.11.3.

SALC Project 88 - Report para 5.11.

Compared with the opt-out regime. 
positively to join in and benefit from the class action. It may also have the effect of reducing the costs associated with the litigation and result in increased efficiency, which is beneficial for all interested parties. ${ }^{14}$

Against the above background, this article will consider and attempt to establish whether there is room for the opt-in class action regime in South African law and when, if at all, the opt-in procedure should be utilised rather than the opt-out procedure. Ultimately, the purpose of the article is to assist in developing a structure that could facilitate the adjudication of class actions in South Africa insofar as this issue is concerned.

Before considering the nature and status of the opt-in class action compared with the opt-out class action in further detail and when, if at all, the opt-in procedure should be utilised rather than the opt-out procedure, the approaches of foreign jurisdictions will be considered.

\section{The approaches of foreign jurisdictions}

The opt-out class action regime is undoubtedly universally more popular than the opt-in class action regime. Conversely, the opt-in class action regime is utilised in only a limited number of foreign jurisdictions, such as the group litigation regime in Sweden and the Group Litigation Order under the Civil Procedure Rules in England and Wales. Further examples of jurisdictions employing an opt-in class action regime are Germany, specifically in the context of certain securities cases, and Denmark. ${ }^{15}$

Ontario subscribes to the opt-out class action regime. ${ }^{16}$ In the Ontario Law Reform Commission Report on Class Actions, ${ }^{17}$ the perceived disadvantages of the opt-in class action regime were considered, specifically the reason why an opt-in class action scenario generally results in a smaller class than when class members are permitted to opt out. ${ }^{18}$ The Ontario Commission confirmed that there is disagreement regarding the conclusions that should be drawn from a failure by individuals to opt into a class action. On the one hand, it has been argued that a failure to opt in reflects disinterest in the class action claim. Conversely, it has been argued that the failure to opt in arises from a variety of factors other than a lack of interest on the part of putative class members, which may result in the size of the class being reduced in an arbitrary and inappropriate manner. Such

SALC Project 88 - Report para 5.11.

Also see Morabito 2003 Tex Int'l LJ 671.

Section 9 of the Class Proceedings Act, 1992, SO 1992, c 6. Also see Walker 2010 https://papers.ssrn.com/sol3/papers.cfm?abstract_id=1491167 5 .

17 Ontario Law Reform Commission Report on Class Actions.

18 Ontario Law Reform Commission Report on Class Actions 467-492. 
factors, according to the Ontario Commission, include fear of involvement in the legal process, concern over the amount of legal costs, fear of sanction from employers or others who may be in a position to retaliate, or the demands of everyday life. ${ }^{19}$ These factors may prevent a class member from taking the steps necessary to opt in. ${ }^{20}$

The Ontario Commission further found that the need to give notice to class members that they must opt into the class action creates difficulties that may result in the exclusion of class members who are not necessarily indifferent to the harm done to them. In many class actions, the identity of class members is initially unknown and, accordingly, notification that they must opt in if they wish to participate in the class action presents a serious problem. To the extent that class members do not receive this information, an opt-in requirement may exclude individuals who never had a real opportunity to express interest in the suit. Even where class members can be located, they may not appreciate the significance of a notice and may fail to read it. They may also experience problems understanding its content. Further, according to the Ontario Commission, even if class members understand the notice, they may be unsure whether the class action applies to them. ${ }^{21}$

The Ontario Commission concluded that low response rates by class members who are required to opt in might be attributable to problems of the sort described above and not necessarily to any general lack of interest in class actions. It stated that it is important to provide increased access to the courts for persons who wish to pursue existing remedies but are unable to do so. It also found that, irrespective of the claims' merits, economic, social and psychological barriers may prevent them from being individually litigated. Class actions can help overcome such barriers and, by providing increased access to the courts, may perform an important function in society. ${ }^{22}$ The Ontario Commission accordingly endorsed the opt-out class action regime inter alia for the reasons set out above. ${ }^{23}$

In Australia the issue as to whether it should adopt an opt-in or opt-out class action model was subject to extensive debate prior to the enforcement of

19 Regardless of whether or not such concerns are ill-founded.

20 Ontario Law Reform Commission Report on Class Actions 132.

21 Ontario Law Reform Commission Report on Class Actions 132-133. This problem does, however, seem to be more prominent in the context of the opt-out regime of class action litigation where, according to Klonoff Class Actions 131, courts are reluctant to certify classes whose members would be difficult to communicate with or identify.

$22 \quad$ Klonoff Class Actions 121.

23 The Ontario Commission's support for the opt-out regime supports the author's contention that access to justice is of crucial importance when determining whether or not class proceedings are appropriate. 
Part IVA of the Federal Court Act, 1976 (Cth). The opt-out model is now embodied in Part IVA of the Federal Court Act, Part 4A of the Supreme Court Act, 1986 (Vic) and Part 10 of the Civil Procedure Act, 2005 (NSW). The Australian Law Reform Commission (ALRC) previously recommended that, "[s]ubject to the provision of appropriate protection, it should be possible to commence a group member's proceeding without first obtaining consent of that group member", That is, opt-out class action proceedings should be possible and are indeed preferable. ${ }^{24}$ When the Federal Court of Australia Amendment Bill, 1991 (Cth) was debated in the House of Representatives, the Attorney General made the following comment, which effectively echoes the view of the Ontario Commission referred to above, in that significant weight was attached to the exclusionary effect of the opt-in class action regime in respect of potential class members and the consequential deprivation of their right to access to justice:

The Government believes that an opt-out procedure is preferable on both grounds of equity and efficiency. It ensures that people, particularly those who are poor or less educated, can obtain redress where they may be unable to take the positive step of having themselves included in the proceedings. It also achieves the goals of obtaining a common, binding decision while leaving a person who wishes to do so free to leave the group to pursue his or her claim separately. ${ }^{25}$

The approach followed by the foreign jurisdictions discussed above is therefore to reject the opt-in class action regime insofar as it arbitrarily reduces the size of potential classes at the expense of putative class members' right of access to justice. For example, the Ontario Commission held that:

In our view, the incorporation of an opt in requirement...would be fundamentally inconsistent with the access to justice rationale that we have endorsed as a basic justification for an expanded class action procedure in Ontario...Since we believe that the meaning of silence is equivocal, and does not necessarily indicate indifference or lack of interest, class members should not be denied whatever benefits are secured by the class action by failing to act at this stage of the proceedings ...26

Similarly, it has been stated that "the opt out model is the more effective means to ensure that the barriers to justice, which class actions are intended to overcome, are reduced". ${ }^{27}$ Hensler states that:

In consumer class actions involving small individual losses, requiring class members to opt in would lead to smaller classes that would likely obtain smaller aggregate settlements ... The social science research on active versus passive assent suggests that minority and low-income individuals

$24 \quad$ ALRC Grouped Proceedings 98-130.

25 Australia House of Representatives Debates 3175.

26 Ontario Law Reform Commission Report on Class Actions 484-485.

27 Ministry of the Attorney General, British Columbia Consultation Document 8. 
might be disproportionately affected by an opt-in requirement, a worrisome possibility. ${ }^{28}$

In its report on class actions, the Alberta Law Reform Institute lists various perceived advantages and disadvantages of both the opt-in and the opt-out class action regimes. It provides that the general advantages of opting out include enhancing access to justice, in that class members are automatically included as part of the class; that class members retain the choice to opt out of the proceedings for whatever reason; and that class members who opt out can pursue individualised litigation. ${ }^{29}$ The disadvantages of opting out include that class members may not receive notice of the class proceedings; that class members who do not opt out are bound by the outcome of the proceedings whether or not they want to be; that the class proceedings may attract claimants who do not want to be part of the proceedings or would not otherwise have litigated; and that opting out operates in violation of the freedom of the individual to choose whether or not to institute proceedings. ${ }^{30}$

Arguments for opting in include that a class member will be bound by the result only if he or she intends to be bound thereto; that all class members who stand to benefit will have shown some interest in the litigation; that the outcome will not be binding upon individuals who do not have knowledge of the lawsuit; that opting in is consistent with the general position in respect of ordinary procedures for commencing legal proceedings; and that persons who do not opt in can litigate their claims outside the ambit of the class action. ${ }^{31}$ Arguments against opting in include that the potential class members who choose not to opt in may not know of the class proceedings; that opting in may deny access to justice to potential class members who fail to opt in because of economic, psychological and social barriers; and that a class action is essentially a permissive joinder device if it is available only to those people who choose to sue together. ${ }^{32}$

It is apparent from the above that the choice between the opt-in and opt-out class action regimes is a difficult one and one that has been subject to debate. Our courts have also not provided sufficient guidance on this issue. The following part of this note accordingly considers, with regard to the

Hensler Class Action Dilemmas 476.

ALRI Class Actions 95.

ALRI Class Actions 96.

ALRI Class Actions 96.

ALRI Class Actions 97. The American Federal Rules of Civil Procedure distinguish between compulsory or necessary joinder and permissive joinder. Necessary joinder entails that parties or claims must be added to the litigation in order for it to proceed. Permissive joinder occurs when the parties or claims are permitted to be added to the litigation. If the parties or claims are not added, the court will still allow the lawsuit to proceed. 
approaches of the foreign jurisdictions referred to above, whether there is room for the opt-in class action regime in South African law and when, if at all, the opt-in procedure should be utilised rather than the opt-out procedure.

\section{Possible approaches in South African law}

The SALC recommended that the court should provide directions in respect of the procedure to be followed as part of the certification process of a class action and that the court should have a wide discretion to determine its own procedures. It further recommended that the court should possess broad general management powers, exercisable either on the application of a party or on the court's own motion. The SALC proposed that legislation should be adopted regulating class actions in South Africa and that the legislation should deal with the questions of when, by whom, to whom, and how notice should be given. As a general rule, according to the SALC, notice to class members and prospective class members should always be given and the court should retain a discretion to make opt-in, opt-out or no notice orders. The court should in all cases consider whether notice of the certification application should be given to all persons eligible to elect to join the class. ${ }^{33}$

It is apparent from the above that the SALC clearly envisaged that circumstances may arise where it would be preferable to require members to opt into class proceedings. To establish the basis for the SALC's recommendation that the court should retain a discretion to make opt-in, opt-out or no notice orders, it is necessary to consider the SALC's Working Paper. In the Working Paper, the SALC stated that provision should be made for opt-in notice in limited situations because there may be circumstances where class members with substantial claims would be severely prejudiced if the class action fails because it was not effectively prosecuted. A judgment in such circumstances would render the individual claims res judicata, therefore preventing further litigation on the same issue. It is therefore important to ensure that class members know of the class action if they are to be bound by the outcome. ${ }^{34}$ Therefore, according to the SALC, circumstances may indeed arise that justify the use of the opt-in procedure rather than the opt-out procedure.

As mentioned above, in an opt-in class action, individual class members who fall within the class definition must, upon receiving the opt-in notice, opt into the class action to form part thereof. Class members who do not opt into the class action, whether it is because they did not receive notice or did

\footnotetext{
33 SALC Working Paper No 57 vii.

$34 \quad$ SALC Working Paper No 57 para 5.32.
} 
receive notice but consciously chose not to opt into the class action, are not bound by its outcome and they will accordingly be at liberty to pursue individual claims against the defendant. Naturally, they will also forfeit the opportunity to share in the benefits obtained by the class in the event of a favourable judgment.

According to the SALC, the advantage of an opt-in notice is that there is certainty as to who the members of the class are and what the aggregate value of the claims is. The defendant is thus in a better position to make a well-reasoned judgement as to his or her liability in order to decide whether to make a settlement offer. ${ }^{35}$ The fact that the opt-in procedure is nothing more than a permissive joinder device is not a problem. Litigation through joinder is made possible by our court rules; however, there is a point at which joinder becomes cumbersome. The SALC states that "it becomes cumbersome when there are more than four or five plaintiffs and extremely cumbersome when there are more than about ten." ${ }^{36}$ Claimants who opt in will be in much the same position as plaintiffs who join in an action, except that the representative will conduct the action on their behalf. The actual management of the action is likely to be simpler and less cumbersome than where a large number of plaintiffs are joined. ${ }^{37}$ The SALC accordingly found that there are circumstances where joinder, although possible, would not be appropriate and that in such cases, the opt-in procedure may be the appropriate means of adjudicating class members' claims.

The SALC recommended that the courts may require that an opt-in notice be given, but stated that it would be the exception rather than the rule. According to the SALC it is obvious why the opt-out procedure is preferable. Similar to the findings of the Ontario Commission, the SALC attached significant weight to financial and social barriers, the existence of which may preclude participation in class proceedings by potential class members. The SALC considered the fact that a large portion of our society is poor, illiterate and uninformed because they have not been properly educated. It is therefore important to ensure that this portion of society benefits from class actions, probably more so than in certain other foreign jurisdictions. Accordingly, the SALC recommended that courts should only that an opt-in notice be given only where there is a possibility that class members may be severely prejudiced. Prejudice in this context entails being bound by a judgment without having knowledge of the class action. The SALC uses the following example: a large number of people suffer damages as a result of an incident such as an airplane crash, and where the individual claims are sufficiently large to make it probable that the claimants would enforce their

SALC Working Paper No 57 para 5.24.

SALC Working Paper No 57 para 5.24.

SALC Working Paper No 57 para 5.24. 
own claims. In such a scenario, according to the SALC, the claimants should not be bound by a judgment unless they have expressly consented to be bound. ${ }^{38}$

From the above example, it can be inferred that the SALC appears to have envisaged that the opt-in procedure should be used in circumstances where the size of the class would be much more limited than where an opt-out procedure would typically be used. In such circumstances, the individual class members would be identifiable as, for example, with the survivors of an airplane accident and, importantly, each class member would have a substantial individual claim. De Vos states that the opt-in regime of class action litigation caters especially for those circumstances where the members of the class have substantial individual claims. He argues that, since the judgment in a class action has a res judicata effect on all the class members except those who have been excluded, it is important that class members with such claims should be apprised of the action and given the option to associate themselves with it. Otherwise they could be severely prejudiced if a class action fails due to mismanagement. ${ }^{39}$

In Mukaddam SCA, Nugent JA held that the fact "[t]hat the plaintiffs might be numerous - in this case it is said that there might be 100 , although there is no reason to think that all will join - is in itself no reason to preclude a joint action. Perhaps there will be more paper - though even that is not necessarily true - but that is no more than administrative inconvenience ...".40 The court footnoted this comment with the following statement:

In the United States a class action is not competent if all the claimants can be joined. Rule 23(a) of the Federal Rules of Civil Procedure require a party seeking certification to demonstrate, amongst other things, that 'the class is so numerous that joinder is impracticable'. ${ }^{41}$

The above-mentioned comments of Nugent JA are problematic in various respects. It is not the case in the United States that, where joinder of all the claimants is possible, class proceedings are not appropriate. American class proceedings may be appropriate where joinder is possible but not necessarily feasible. ${ }^{42}$ If joinder is possible, but would needlessly complicate the litigation of the case, then class action proceedings may be appropriate. ${ }^{43}$ The impracticability of joinder does not entail impossibility. ${ }^{44}$ Accordingly, the identifiability of individual class members will form part of

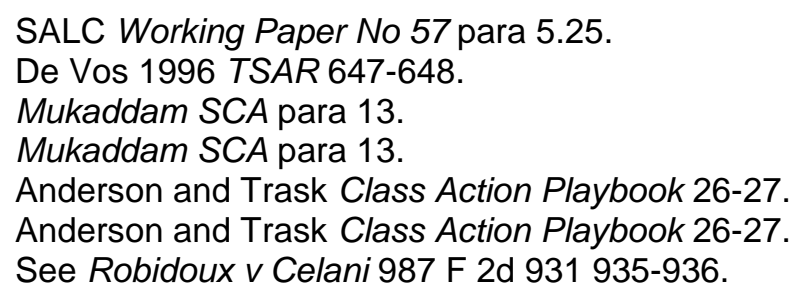


the assessment of the impracticability of joinder - however, it is not the only consideration in determining the practicability of joinder as compared with class proceedings. ${ }^{45}$

It further appears that Nugent JA did not give proper consideration to the judgment of Cameron JA in Ngxuza, where he held that joinder presupposes that prospective plaintiffs will approach courts en masse, but that this often fails to materialise insofar as the "various parties who have the common interest are isolated, scattered and utter strangers to each other". ${ }^{46}$ In such circumstances, the conditions for group action through joinder do not exist. According to Cameron JA, society cannot simply set up courts and wait for litigants to bring their complaints, as barriers may exist that preclude their participation in litigious proceedings; hence the need for class proceedings. ${ }^{47}$ Simply stating that a numerous class consisting of approximately 100 claimants is insufficient to preclude litigation through joinder - or stated differently, that joinder is possible where the class consists of 100 claimants - does not take account of the practicalities associated with joinder or the benefits of a class action. Such an approach disregards the considerations that are relevant in determining the appropriateness of class proceedings as a means of adjudicating the claims of class members.

Linkside $v$ Minister of Basic Education ${ }^{48}$ serves as a fitting example and evidences what the SALC and De Vos had in mind when stating that circumstances may arise where the use of the opt-in procedure is both necessary and justifiable. Linkside is the first South African opt-in class action. A class action was instituted in the Eastern Cape High Court, Grahamstown, against the Minister of Basic Education, the DirectorGeneral of the National Department of Basic Education, the MEC, Department of Basic Education in the Eastern Cape Province, and the Head of the Department of Basic Education in the Eastern Cape Province, seeking an order directing the respondents to appoint educators permanently to allocated vacant substantive posts and to reimburse schools that were being forced to pay educators whom the State was required to pay. The class action was instituted on behalf of all public schools registered as such in the Eastern Cape whose vacant substantive posts were not filled on a permanent basis and who were forced to pay educators whom the State was required to pay. The schools were afforded the opportunity to opt

\footnotetext{
$45 \quad$ Klonoff Class Actions 40.

46 Permanent Secretary, Department of Welfare, Eastern Cape v Ngxuza 20014 SA 1184 (SCA) (hereafter Ngxuza) paras 4-5.

$47 \quad$ Ngxuza paras 4-5.

$48 \quad$ Linkside $v$ Minister of Basic Education (HC) (unreported) case number 3844/2014 of 17 December 2014 (hereafter Linkside).
} 
into the class action by sending a written notice to the legal representatives of the class. ${ }^{49}$ The opt-in class action was consented to by the Department of Basic Education. The case was subsequently settled, in terms of which settlement the Department of Basic Education, Eastern Cape was ordered to pay R81-million to the schools that opted into the class action.

In Linkside, the number of class members who opted in was limited to 90, all of whom were identifiable, and the claims of the individual class members were large enough to make it likely that they would litigate independently in the absence of a class action. In this regard, the differences between Linkside and other South African class action cases, including Ngxuza, Children's Resource Centre Trust $v$ Pioneer Food (Pty) Ltd ${ }^{50}$ and Mukaddam SCA, are obvious. ${ }^{51}$ For example, in Ngxuza Cameron JA stated that:

The situation seemed pattern-made for class proceedings ... Their individual claims are small: the value of the social assistance they receive ... would secure them hardly a single hour's consultation at current rates with most urban lawyers. They are scattered throughout the Eastern Cape Province, many of them in small towns and remote rural areas ... . ${ }^{52}$

He further referred to "[t]he circumstances of this particular case - unlawful conduct by a party against a disparate body of claimants lacking access to individualised legal services, with small claims unsuitable for if not incapable of enforcement in isolation ...".53

In Children's Resource Centre Trust, Wallis JA held that "[t]he class of people on whose behalf the appellants seek to pursue claims ... is both large and in general poor. Any claims they may have against the respondents are not large enough to warrant their being pursued separately...". 54

Because the judgment has a res judicata effect on all class members other than those who have been excluded, the class members in Linkside should not be bound by a judgment unless they have been apprised of the action

The written notice in terms of which class members opted into the class action had to set out a list of substantive vacancies on the 2014 post establishment at the school concerned and the payments made by the school to educators in permanent posts (together with proof of such payments) and which had not been reimbursed by the Department of Basic Education. Children's Resource Centre Trust v Pioneer Food (Pty) Ltd 20132 SA 213 (SCA) (hereafter Children's Resource Centre Trust).

51 Rather unsurprisingly, the majority of South African class actions pertain to the purported vindication of certain socio-economic rights, as was the case in the Ngxuza, Children's Resource Centre Trust and Mukaddam judgments.

$52 \quad$ Ngxuza para 11. Emphasis added.

$53 \quad$ Ngxuza para 14. Emphasis added.

54 Children's Resource Centre Trust para 16. Emphasis added. 
and given the option to associate themselves with it. The more targeted optin mechanism was accordingly preferable, otherwise the putative class members could be severely prejudiced if the class action failed due to mismanagement.

As we have seen, according to the Ontario Commission, it is questionable whether it is necessary to protect the interests of individuals with large claims from any prejudice that might ensue if the class action were not prosecuted skilfully. The Ontario Commission stated that, where a class member wanted to institute proceedings independently, he or she would be free to do so by opting out of the class action. ${ }^{55}$ However, the possibility exists that the opt-out notice may not come to the attention of the class member, that the class member may consequently fail to opt out of the class action, and that an unsuccessful outcome of such action due to mismanagement would be binding on the class member. The opt-in regime, with its individualised notice, is accordingly preferable in the circumstances. ${ }^{56}$

The purpose of affording the court a discretion to choose between the type of class action procedure to be followed is inter alia to determine, with reference to the facts of the specific case, whether ordering that the opt-in procedure be utilised would have the effect of potentially denying people a legal remedy simply because they may fail to comprehend the opt-in requirement, may be fearful of taking action, or may otherwise be precluded from opting into the class action. Therefore, when considering the potential utilisation of the opt-in regime rather than the opt-out regime, this discretion should operate to protect those individuals who may be excluded from the class proceedings by virtue of the nature of opt-in proceedings.

Linkside reinforces the submission that there is scope in South African law for the opt-in class action regime, coupled with the discretion of our courts to make opt-in, opt-out or no-notice orders. The finding in Mukaddam SCA that joinder is appropriate where the class members are identifiable effectively obviates the need for the opt-in class action regime. It appears that Nugent JA subscribed to the view that the opt-in procedure is nothing more than a permissive joinder device. This cannot be correct. As mentioned, there are circumstances where the class members are identifiable but where joinder is nonetheless cumbersome and unfeasible. A preferable approach is accordingly one in terms of which our courts are

55 Ontario Law Reform Commission Report on Class Actions 485.

56 According to the Ontario Law Reform Commission Report on Class Actions 469, where the opt-in procedure is followed, individual notice should be sent to identifiable class members. 
afforded a discretion to choose, with regard to the circumstances of each case, whether to require opt-in, opt-out or no-notice at all.

\section{Conclusion}

The choice between opt-in and opt-out procedures is important insofar as the exercise of the choice may have the effect of excluding a large number of people from the class proceedings. Specifically in the context of the optin procedure where claimants are required to actively rather than passively join the class proceedings, it is likely that the class would be smaller than where the opt-out procedure is utilised, potentially infringing upon the right to access to justice of the excluded class members.

However, this does not necessarily mean that there is no choice to be made between opt-in and opt-out class actions. It may be that the circumstances of the case are such that the opt-in procedure is indeed preferable to the opt-out procedure. As was the case in Linkside, this may occur where the court is confronted with a relatively small group ${ }^{57}$ of individual claimants each of whom is identifiable and especially where each claimant has a substantial individual claim. In this regard, the court should assess whether the size of the claimants' individual claims is such that it is unlikely that they would, in the absence of class proceedings, litigate independently. If it is likely that they would litigate independently, then those claimants should be given an opportunity to opt into the proceedings.

If in such a case the opt-out procedure rather than the opt-in procedure is utilised, it may be prejudicial to individuals who have no knowledge of the class proceedings but who are bound by its outcome, for if the opt-in procedure is followed and an individual is not given notice, then the class action judgment would not be binding upon that individual and he or she would be at liberty to pursue individualised litigation. The primary advantage of providing the court with judicial discretion to choose between requiring opt-in, opt-out and no-notice orders is that it enables the court to decide, with reference to the circumstances of the particular case, which procedure would be most suited to the overall disposition of the case. ${ }^{58}$

\section{Bibliography}

\section{Literature}

\section{ALRC Grouped Proceedings}

$57 \quad$ That is nevertheless large enough to render joinder in terms of the court rules cumbersome and unfeasible.

58

$$
\text { ALRI Class Actions. }
$$


Australian Law Reform Commission Grouped Proceedings in the Federal Court Report No 46 (Australian Government Publication Services Canberra 1988)

ALRI Class Actions

Alberta Law Reform Institute Class Actions, Final Report No 85 (Edmonton Alberta Law Reform Institute 2000)

Anderson and Trask Class Action Playbook

Anderson B and Trask A The Class Action Playbook (LexisNexis New York 2014)

Australia House of Representatives Debates

Australia House of Representatives Debates (14 November 1991)

De Vos 1996 TSAR

De Vos LR "Reflections on the Introduction of a Class Action in South Africa" 1996 TSAR 639-657

Hensler Class Action Dilemmas

Hensler DR Class Action Dilemmas: Pursuing Public Goals for Private Gain (RAND Institute for Civil Justice Santa Monica 2000)

Klonoff Class Actions

Klonoff $\mathrm{RH}$ Class Actions and Other Multi-party Litigation in a Nutshell $4^{\text {th }}$ ed (Thomson West St Paul 2012)

Ministry of the Attorney General, British Columbia Consultation Document Ministry of the Attorney General, British Columbia Consultation Document: Class Action Litigation for British Columbia (The Ministry Victoria 1994)

Morabito 2003 Tex Int'l LJ Morabito V "Judicial Supervision of Individual Settlements with Class Members in Australia, Canada and the United States" 2003 Tex Int' LJ 663728

Ontario Law Reform Commission Report on Class Actions Ontario Law Reform Commission Report on Class Actions (Ontario Law Reform Commission Ontario 1982)

SALC Working Paper No 57

South African Law Commission Working Paper No 57: The Recognition of a Class Action in South African Law (The Commission Pretoria 1995)

SALC Project $88-$ Report 
South African Law Commission Project 88 - Report: The Recognition of Class Actions and Public Interest Actions in South African Law (The Commission Pretoria 1998)

\section{Case law}

Children's Resource Centre Trust v Pioneer Food (Pty) Ltd 20132 SA 213 (SCA)

Linkside $v$ Minister of Basic Education $(\mathrm{HC})$ (unreported) case number 3844/2014 of 17 December 2014

Mukaddam v Pioneer Foods (Pty) Ltd 20132 SA 254 (SCA)

Mukaddam v Pioneer Foods (Pty) Ltd 20135 SA 89 (CC)

Permanent Secretary, Department of Welfare, Eastern Cape v Ngxuza 2001 4 SA 1184 (SCA)

Robidoux v Celani 987 F 2d 931

\section{Legislation}

American Federal Rules of Civil Procedure

Civil Procedure Act, 2005 (NSW)

Class Proceedings Act, 1992

England and Wales Civil Procedure Rules

Federal Court Act, 1976 (Cth)

Federal Court of Australia Amendment Bill, 1991 (Cth)

Supreme Court Act, 1986 (Vic)

\section{Internet sources}

Walker 2010 https://papers.ssrn.com/sol3/papers.cfm?abstract id $=1491167$

Walker J 2010 Class Proceedings in Canada: Report for the 18th Congress of the International Academy of Comparative Law https://papers.ssrn.com/sol3/papers.cfm?abstract_id=1491167 accessed 23 January 2019

\section{List of Abbreviations}


ALRC

ALRI

CC

SALC

SCA

Tex Int'I LJ

TSAR
Australian Law Reform Commission

Alberta Law Reform Institute

Constitutional Court

South African Law Commission

Supreme Court of Appeal

Texas International Law Journal

Tydskrif vir die Suid-Afrikaanse Reg 